\title{
PERBEDAAN PENGGUNAAN PAKET PEMBELAJARAN DAN MOTIVASI BELAJAR TERHADAP HASIL BELAJAR MATA KULIAH PENGANTAR PENDIDIKAN
}

\author{
Dedy Ariyanto \\ IKIP PGRI JEMBER \\ dedyariyanto903@gmail.com
}

\begin{abstract}
ABSTRAK
Penelitian ini bertujuan untuk mengetahui perbedaan penggunaan paket pembelajaran dan motivasi belajar terhadap hasil belajar mahasiswa pada mata kuliah pengantar pendidikan. Penelitian ini menggunakan desain quasi eksperimen dengan menggunakan faktorial $2 \times 2$. Mahasiswa yang terlibat dalam penelitian ini sejumlah 60 mahasiswa program studi pendidikan khusus, dengan dibagi menjadi 2 kelompok yaitu kelompok eksperimen yang diberi perlakuan yaitu menggunakan paket pembelajaran dan kelompok kontrol yang tidak diberi perlakuan yaitu menggunakan buku teks. Hasil penelitian didapatkan adalah 1). didapatkan nilai $F_{\text {hitung }}$ sebesar 54,079 dengan Sig. 0,021. Karena nilai Sig. $<0,05$ maka $\mathrm{H}_{0}$ ditolak dan $\mathrm{H}_{1}$ diterima, maka disimpulkan ada perbedaan antara hasil belajar antara yang menggunakan Paket Pembelajaran dan yang menggunakan buku teks. 2). Didapatkan nilai $F_{\text {hitung }}$ sebesar 4,980 dengan Sig. 0,030. Karena nilai Sig. $<0,05$ maka $\mathrm{H}_{0}$ ditolak dan $\mathrm{H}_{1}$ diterima, maka disimpulkan ada perbedaan antara hasil belajar antara mahasiswa dengan motivasi tinggi dan motivasi rendah. 3). Didapatkan nilai $F_{\text {hitung }}$ sebesar 1,796 dengan Sig. 0,047. Karena nilai Sig. $<0,05$ maka $\mathrm{H}_{0}$ ditolak dan $\mathrm{H}_{1}$ diterima, maka disimpulkan ada interaksi signifikan antara hasil belajar mahasiswa yang menggunakan Paket Pembelajaran dan buku teks serta perbedaan motivasi yang memberikan pengaruh terhadap hasil belajar Pengantar Pendidikan.
\end{abstract}

Kata Kunci: Hasil Belajar, Motivasi Belajar, Paket Pembelajaran

\begin{abstract}
This study aims to determine differences in the use of learning packages and learning motivation towards student learning outcomes in introductory courses in education. This study uses a quasi-experimental design using $2 \times 2$ factorial. The students involved in this study were 60 special education study program students, divided into 2 groups: the experimental group that was treated using a learning package and the control group that was not treated, namely using a textbook. The results obtained are 1). Fcount value of 54.079 was obtained with Sig. 0.021. Because the value of Sig. <0.05 then HO is rejected and HI is accepted, then it is concluded there is a difference between learning outcomes between those who use the Learning Package and those who use textbooks. 2). Obtained Fcount value of 4.980 with Sig. 0.030. Because the value of Sig. <0.05 then HO is rejected and H1 is accepted, then it is concluded there is a difference between learning outcomes between students with high motivation and low motivation. 3). Obtained Fcount value of 1.796 with Sig. 0.047. Because the value of Sig. <0.05 then HO is rejected
\end{abstract}


and $\mathrm{HI}$ is accepted, then it is concluded that there is a significant interaction between student learning outcomes using Learning Packages and textbooks as well as differences in motivation that have an influence on learning outcomes in Introduction to Education.

Keywords: Learning Outcomes, Learning Motivation, Learning Packages

\section{PENDAHULUAN}

Perkembangan ilmu pengetahuan saat ini berkembang dengan pesat dan sangat berdampak dengan kehidupan manusia. Selain itu juga berdampak pada hampir semua aspek kehidupan. Adanya perkembangan itu juga berdampak pada duania pendidikan, maka diperlukan perubahan untuk mengatasi hal tersebut diantaranya adalah proses belajar mengajar. Pendidikan secara umum adalah segala upaya yang direncanakan dalam mempengaruhi orang lain baik individu, kelompok ataupun masyarakat sehingga mereka melakukan apa yang diharapakan oleh para pelaku dalam dunia pendidikan (Notoatmojo, 2003).

Menurut Undang-undang Republik Indonesia Tahun 2003 tentang Sistem Pendidikan Nasional pasal 1 mengatakan bahwa pendidikan adalah usaha sadar dan terencana untuk mewujutkan suasana belajar dan proses pembelajaran agar peserta didik aktif dalam mengembangkan potensi yang dimilikinya agar memiliki nilai seperti spiritual keagamaan, pengendalian diri, kepribadian, kecerdasan, akhlak mulia, serta keterampilan yang diperlukan untuk dirinya, masyarakat, bangsa dan negara. Berdasarkan hal diatas maka pendidikan sangat diperlukan dalam rangka adamya perubahan tingkah laku dan peningkatan mutu pada setiap manusia.

Proses belajar mengajar, guru dan dosen sering melakukan dengan metode konvensional atau ceramah, dimana guru sering melakukan sebuah keputusan belajar dan para peserta didik mengikuti keputusan tersebut, itu juga berlaku pada perkuliahan di perguruan tinggi. Hasil dari semua itu peserta didik lebih pasif dalam proses pembelajaran serta menerima apapun itu yang disampaikan oleh guru/dosen. Akibat dari semua itu, peserta didik kurang ingin memiliki rasa ingin tahu dalam proses pembelajaran, sehingga proses pembelajaran menjadi membosankan. Paket pembelajaran adalah salah satu solusi yang dianggap untuk mampu untuk mengaktifkan minat belajar peserta didik atau rasa ingin tau terkait materi yang akan dipelajari.

Menurut Dick \& Carey (1996) mengungkapkan bahwa paket pembelajaran berisi tentang materi seharusnya mempertimbangkan informasi yang berupa tulisan atau sejenisnya yang bisa digunakan oleh siswa untuk mencapai tujuan pembelajaran. Sedangkan Romiszowski (1986) mengungkapkan bahwa paket pembelajaran harus mempertimbangkan aspek 4 aspek antara lain: 1). Aspek akademik, dimana paket pembelajaran harusnya dapat memfasilitasi siswa untuk mengembangkan kemampuan dalam ranah kognitif, afektif dan psikomotorik, 2). 
Aspek sosial, dimana paket pembelajaran harus bisa memberikan kemampuan pada siswa untuk bisa berkomunikasi secara menyeluruh pada semua lapisan masyarakat kapanpun dan dimanapun tempatknya, 3). Aspek rekreasi, dimana paket pembelajaran harus terlihat menarik, isi materi tidak membosankan , tampilan harus menarik sehingga meningkatkan minat belajar, 4). Aspek pengembangan pribadi, paket pembelajaran harus memiliki kesan bagi pemakainya dalam hal ini adalah siswa, serta memenuhi kebutuhan baik dari sisi akademik, sosial, rekreasi, maupun kebutuhan individunya.

Dikcson \& Leonard mengemukakan bahwa ada 12 unsur penting dalam paket pembelajaran antara lain: Topic statemenyaitu pokok masalah yang akan dipelajari, Rationalyaitu pernyataan singkat yang mengungkapkan rasional dan kegunaan materi untuk siswa, Concep statement and prerequisite yaitu pernyataan yang mendefinisikan ruang lingkup dan sekuen dari konsep-konsep dalam hubungannya dengan konsep lain dalam bidang pokok, conceptyaitu pernyataan tentang kemampuan apa yang dikuasai oleh siswa, behavior objective, pretes yaitu untuk mengukur kemampuan awal yang dimiliki oleh siswa, suggest teacher techniquesyaitu petunjuk yang diberikan oleh guru untuk dapat membantu peserta didik, suggest student activities yaitu yaitu aktifitas yang menunjukkan siswa melakukan sesuatu untuk mecapai yujuan pembelajaran, multimedia resourcesyaitu menunjukkan sumber dan berbagai pilihan materi yang dapat digunakan untuk mengajarkan paket pembelajaran, posttes and evaluationyaitu menerapkan kondisi dan kriteria penilaian terhadap penampilan siswa, remidiation plans yaitu untuk membantu siswa yang lemah dalam mencapai kriteria tertentu, general reaaessment potential yaitu mengacu pada kebutuhan penilaian terus menerus dari unsur paket pembelajaran

Menurut Gagne (1975) mengemukakan bahwa pembelajaran adalah suatu rangkaian kejadian atau peristiwa yang bisa mempengaruhi siswa yang menyebabkan terjadinya proses belajar. Oleh karena itu pembelajaran sebenarnya merupakan sebuah proses interaksi antara peserta didik dengan lingkungan, sehingga terjadinya perubahan tingkah laku ke arah yang positif. Adad banyak faktor yang mempengaruhi terjadinya sebuah interaksi tersebut, faktor itu bisa dari dalam/internal maupun dari luar/eksternal pada individu peserta didik. Dalam proses pembelajaran tugas utama guru/dosen addalah mengkondisikan lingkungan sekitar guna menunjang adanya perubahan tingkah laku perserta didik.

Sedangkan menurut Dick \& Carey (1996) mengemukakan pendapat bahwasanya pembelajaran adalah suatu kegiatan yang bersifat menyeluruh untuk mencapai tujuan pembelajaran yang terdiri dari: 1) aktivitas pra instruksional yaiyu aktivitas yang bertujuan untuk memberikan motivasi belajar, menyampaikan tujuan pembelajaran, memberikan informasi apa saja yang dibutuhkan peserta didik sebelum mengikuti materi pembelajaran, 2) menyampaikan informasi yang intinya terkait dengan isi pembelajaran, urutan materi, dan tahapan pembelajaran yang akan dilaksanakan untuk mencapai tujuan 
yang akan dicapai, 3) adanya partisipasi dari peserta didik serta adanya feedback dalam proses pembelajaran, 4) adanya alat ukur berupa tes yang berguna untuk mengukur seberapa jauh pencapaian tujuan pembelajaran sudah dicapai, 5) adanya tindak lanjut dalam hal pengayaan dan remedial.

Proses belajar motivasi sangat berperan penting, hal ini karena dengan adanya motivasi belajar yang tinggi maka peserta didik akan bisa lebih semangat dalam proses belajarnya, begitu pula sebaliknya jika motivasi belajar rendah dipastikan anak kurang bersemangat dalam mengikuti proses pembelajaran.

Belajar dan motivasi merupakan suatu hal yang sangat berkaitan dan saling mempengaruhi dalam berbagai hal. Motivasi bisa dikatakan sebagai modal dalam proses belajar. Menurut Sardiman (2011) mengatakan bahwa terdapat ciri-ciri seseorang yang memiliki motivasi belajar antara lain: 1). Anak memiliki ketekunan dalam menghadapi atau menyeleseikan sebuah tugas, dimana anak yang memiliki kebiasaan bekerja keras secara terus menerus sampai tugas yang diberikan selesei akan memunculkan keterampilan dan kreatifitas yang lebih, 2). Anak memiliki keuletasn dan tidak mudah menyerah, dimana anak model seperti ini tentu anak yang memiliki tipikal tidak gampang menyerah, suka mencari alternatif dalam menyeleseikan tugas, 3). Memiliki semangat yang tinggi tanpa perlu mengharapkan imbalan apapun dari orang lain, 4). Selalu ingin berprestasi, dimana anak akan tidak mudah menyerah ataupun tidak cepat merasa puas terhadap apa yang telah dicapainya, 5). Memiliki sifat rasa ingin tahu yang tinggi, sering memberikan gagasan, usulan, pertanyaan dalam sebuah permasalahan atau sebuah materi, 6). Rajin belajar, penuh semangat, dan enang akan belajar, 7). Mampu mempertahankan pendapat-pendapatnya jika pendapat itu menurutnya benar, 8). Memiliki orientasi masa depan, tidak berfikir kesenangan sesaat, memiliki pandangan yang bersifat global, 9). Menyukai hal-hal yang bersifat baru, menyukai tantangan, mencari pemecahan soal-soal yang dihadapi.

Berdasarkan hasil uraian diatas, maka dalam penelitian ini terdapat 3 masalah utama yang harus dipecahkan oleh peneliti yaitu: 1) apakah ada perbedaan antara mahasiswa yang diajar menggunakan paket pembelajaran dan yang diajar menggunakan buku teks. 2) apakah ada perbedaan hasil belajar pada mahasiswa dengan motivasi tinggi dan motivasi rendah. 3) apakah ada interaksi signifikan antara perbedaan penggunaan paket pembelajaran dan buku teks serta perbedaan motivasi belajar dalam memberikan pengaruh yang berbeda terhadap hasil belajar mata kuliah pengantar pendidikan. Adapun tujuan penelitian ini adalah untuk mengetahui perbedaan penggunaan paket pembelajaran dan motivasi belajar terhadap hasil belajar mahasiswa pada mata kuliah pengantar pendidikan.

\section{METODE PENELITIAN}

Penelitian ini adalah penelitian yang membandingkan antara signifikansi antar variabel bebas dan variabel terikat sehingga pendekatan dari variabel ini adalah kuantitatif komparatif. Penelitian ini menggunakan rancangan desain 
penelitian quasi eksperimen dengan desain eksperimen yang digunakan adalah nonrandomized pretest-posttest control grup desaign menggunakan faktorial 2 x 2 (Seniati et al, 2005). Variabel bebas dalam penelitian ini adalah Paket Pembelajaran dan variabel terikat adalah hasil belajar mata kuliah Pengantar Pendidikan, sedangkan motivasi belajar dalam penelitian ini adalah variabel moderat. Dalam penelitian ini, populasi yang digunakan adalah seluruh mahasiswa Program studi Pendidikan Luar Biasa Semester 2 yang terdiri dari 2 kelas. Sedangkan sampel yang digunakan adalah 2 kelas yang ada pada semester 2, maka dari itu penelitian ini adalah penelitian populasi.

Instrumen dalam penelitian ini yang digunakan adalah tes dan angket. Tes digunakan untuk mengukur hasil belajar mahasiswa sedangkan angket digunakan untuk mengukur motivasi belajar mahasiswa. Instrumen motivasi belajar yang dikembangkan untuk digunakan terdapat 20 item pertanyaan, sedangkan untuk instrumen hasil belajar berupa tes yang dikembangkan untuk digunkan berjumlh 20 item pertanyaan. Hasil validitas instrumen tes hasil belajar dikatakan valid apabila nilai Sig.(1-tailed) < 0,0,50 dan bila nilai koefisien korelasi memiliki nilai Sig (1-tailed) > 0,050 maka item tersebut tidak valid.

Berdasarkan hasil perhitungan didapatkan 15 item valid dan 5 item tidak valid. berdasarkan 15 item valid semua indikator telah terwakili dan tes hasil belajar dapat digunakan untuk pengambilan data. Sedangkan untuk hasil uji validitas skala motivasi juga dilakukan dengan bantuan SPSS 20 for windows. Item skala motivasi dikatakan valid jika memiliki korelasi item total bernilai positif dengan sig kurang dari 0,050 (sig < 0,050), namun jika item total bernilai negatif maupun positif deng sig lebih dari 0,05 ( $\mathrm{sig}>0,050)$ maka dikatakan item tidak valid. berdasarkan hasil perhitungan didapatkan 17 item valid dan 3 item tidak valid. dari 17 item valid diketahui semua indikator telah terwakili sehingga semua instrumen motivasi dapat digunakan untuk pengambilan data. sedangkan untuk uji reliabilitas suatu intrumen adalah 0,60. Jika nilai Alpha Cronbach lebih dari 0,60 maka dikatakan reliabel dan jika kurang dari 0,60 dikatakan tidak reliabel yang berarti item tersebut perlu dihilangkan atau diperbaiki. Berdasarkan hasil pengujian didapatkan nilai reliabel 0,952 untuk item motivasi dan 0,607 untuk item hasil belajar. Berdasarkan hasil tersebut item angket motivasi dan tes hasil belajar dikatakan reliabel dan bisa digunakan.

Penelitian ini terdapat 4 data tes dan 2 data motivasi. 4 data tes adalah data pre tes kelompok kontrol, data post tes kelompok kontrol, data pre tes kelompok eksperimen, dan data post tes kelompok ekperimen, dari 4 data diatas dikembangkan ada 2 data yaitu gain skor kelompok kontrol dan gain skor kelompok eksperimen. Sedangkan 2 data motivasi belajar adalah data motivasi kelompok kontrol dan data motivasi kelompok eksperimen. Menurut Seniati, et al (2005) gain skor adalah selisih antara nilai pre tes dan nilai pos tes. Selisih tersebut merupakan ukuran hasil belajar yang telah diberikan perlakuan. Teknik analisis yang digunakan adalah analisis teknik statistik deskriptif. Sedangkan 
untuk pengujian hipotesis digunakan analisis statistik inferensial untuk mengambil kesimpulan. Teknik analisis statistik deskriptif yang digunakan untuk mencari perbedaan adalah Analisis Varian dua jalur $(2 \times 2)$ dimana perhitungannya akan menggunakan SPSS 16.00 for Windows.

\section{HASIL DAN PEMBAHASAN}

Hasil belajar mahasiswa mata kuliah pengantar pembelajaran pada kelompok eksperimen dimana menggunakan paket pembelajaran ternyata lebih baik dari pada hasil belajar mahasiswa pada kelompok kontrol yang mana menggunakan buku teks. Hal ini seperti yang dijabarkan pada tabel analisis deskriptif dibawah ini

Tabel 1

Ringkasan Analisis Deskriptif

\begin{tabular}{llllll}
\hline Hasil Belajar & $\mathrm{N}$ & Minimum & Maximum & Mean & Std.Deviation \\
\hline Kel Kontrol & 30 & $-1,00$ & 7,00 & 1,2900 & 2,040 \\
Kel Eksperimen & 30 & 1,00 & 7,00 & 4.488 & 1,222 \\
\hline
\end{tabular}

(data diolah tahun 2018)

Untuk data motivasi belajar terdapat 2 data yaitu motivasi tinggi dan motivasi rendah. Hal ini seperti yang dijabarkan pada tabel analisis deskriptif dibawah ini

Tabel 2

Ringkasan Analisis Deskriptif

\begin{tabular}{lcllll}
\hline Motivasi & $\mathrm{N}$ & Minimum & Maximum & Mean & Std.Deviation \\
\hline Tinggi & 30 & 0,00 & 7,00 & 3,250 & 2,020 \\
Rendah & 30 & $-2,00$ & 7,00 & 2,290 & 7,700 \\
\hline (data diolah tahun 2018) & & & &
\end{tabular}

Hasil belajar berdasarkan interaksi antara paket pembelajaran dan motivasi belajar dijabarkan dalam tabel di bawah ini

Tabel 3

Ringkasan interaksi antar variabel

\begin{tabular}{llllll}
\hline kelompok & $\begin{array}{l}\text { Motivasi } \\
\text { belajar }\end{array}$ & $\begin{array}{l}\text { Mean hasil } \\
\text { belajar }\end{array}$ & $\mathrm{N}$ & Std. Deviasi & Urutan \\
\hline \multirow{2}{*}{ Kontrol } & Rendah & 0,400 & 15 & 2,070 & 4 \\
& Tinggi & 3,251 & 15 & 1,770 & 3 \\
\multirow{2}{*}{ Eksperimen } & Rendah & 3,255 & 14 & 1,760 & 2 \\
& Tinggi & 4,701 & 16 & 1,051 & 1 \\
\hline
\end{tabular}

(data diolah tahun 2018) 
Berdasarkan hasil perhitungan, didapatkan bahwa 1). Didapatkan nilai $F_{\text {hitung }}$ sebesar 54,079 dengan Sig. 0,021. Karena nilai Sig. < 0,05 maka $\mathrm{H}_{0}$ ditolak dan $\mathrm{H}_{1}$ diterima, maka disimpulkan ada perbedaan antara hasil belajar antara yang menggunakan Paket Pembelajaran dan yang menggunakan buku teks. 2). Didapatkan nilai $F_{\text {hitung }}$ sebesar 4,980 dengan Sig. 0,030. Karena nilai Sig. < 0,05 maka $\mathrm{H}_{0}$ ditolak dan $\mathrm{H}_{1}$ diterima, maka disimpulkan ada perbedaan antara hasil belajar antara mahasiswa dengan motivasi tinggi dan motivasi rendah. 3). Didapatkan nilai $F_{\text {hitung }}$ sebesar 1,796 dengan Sig. 0,047. Karena nilai Sig. < 0,05 maka $\mathrm{H}_{0}$ ditolak dan $\mathrm{H}_{1}$ diterima, maka disimpulkan ada interaksi signifikan antara hasil belajar antara yang menggunakan Paket Pembelajaran dan buku teks serta perbedaan motivasi dalam memberikan pengaruh terhadap hasil belajar Pengantar Pendidikan.

Hasil penelitian membuktikan bahwa terdapat perbedaan yang signifikan antara kelas yang diberi paket pembelajaran dan yang diberi buku teks pada mata kuliah pengantar pendidikan. Simpulan ini diperoleh dari pengambilan keputusan berdasarkan pada nilai Sig. $<0,05$ maka $\mathrm{H}_{0}$ ditolak dan $\mathrm{H}_{1}$ diterima, maka disimpulkan ada perbedaan antara hasil belajar antara yang menggunakan Paket Pembelajaran dan yang menggunakan buku teks. Hasil ini dijelaskan bahwa bentuk dari paket pembelajaran yang dilengkapi dengan petunjuk instruksional dan tahapan yang jelas menjadi kelebihan sendiri yang tidak ditemui dalam buku teks. Arahan instruksional disini akan menuntun siswa secara mandiri untuk bisa mempelajari paket pembelajaran diluar jam mata kuliah, sehingga ini menjadi nilai tambah dan tidak tergantung pada kehadiran dosen di dalam kelas.

Tahapan materi yang disampaikan dalam paket pembelajaran dapat diatur seddemikian sehingga peserta didik bisa mendapatkan materi secara utuh dan menyeluruh serta melalui tahapan-tahapan yang runtun. Dalam hal ini sesuai dengan pendapat Sudjana (2014) yang mengemukakan bahwa paket pembelajaran dan modul adalah suatu paket pengajaran yang berkenan dengan suatu unit terkecil bertahap (dipelajari secara individual dari satu unit ke unit lainnya) pada satu pokok/topik ke pokok/topik lainnya, bisa dilakukan secara mandiri, peserta didik dapat mampu untuk mengontrol sendiri intensitas belajarnya.

Berdasarkan penelitian Leatemia (2008) mengukapkan bahwa paket pembelajaran memberikan hasil yang lebih baik, terdapat perbedaan yang signifikan yang menggunakan paket pembelajaran dan tidak. Sedangkan hasil penelitian dari Saadah, et al (2007) mengungkapkan bahwa paket pembelajaran dapat meningkatkan hasil belajar kognitif dengan rata-rata gain skor meningkat antara 0,30 pada siklus pertama dan 0, 38 pada siklus kedua. Selain itu hasil penelitian juga meningkatkan hasil belajar afektif dalam setiap indikator ketercapaiannya antara lain kerjasama dalam kelompok sebesar 12,5\%, keaktifan melakukan praktikum 7\%, keberanian menjawab dan bertanya sebesar 19,9\%. Sedangkan pada hasil belajar psikomotorik juga mengalami peningkatan sebesar $7 \%$. 
Pada hasil hipotesis kedua dinyatakan didapatkan nilai $\mathrm{F}_{\text {hitung }}$ sebesar 4,980 dengan Sig. 0,030. Karena nilai Sig. $<0,05$ maka $\mathrm{H}_{0}$ ditolak dan $\mathrm{H}_{1}$ diterima, maka disimpulkan ada perbedaan antara hasil belajar antara mahasiswa dengan motivasi tinggi dan motivasi rendah. Motivasi belajar memang memiliki pengaruh bagi keberhasilan peserta didik, banyak penelitian yang mengungkap bahwa peserta didik yang memiliki motivasi belajar tinggi akan lebih berhasil dalam hal hasil belajar daripada mereka yang memiliki motivasi belajar rendah.

Jika kita melihat ke belakang, tentunya motivasi belajar bukanlah satusatunya faktor yang mempengaruhi hasil belajar seorang anak, akan tetapi faktorfaktor lain tersebut memang diabaikan dalam penelitian ini. Slavin (2005) mengemukakan bahwa motivasi belajar adalah kecenderungan untuk berusaha untuk mencapai keberhasilan dan memilih kegiatan yang berorientasi pada tujuan pembelajaran, keberhasilan pembelajaran ataupun kegagalan dalam pembelajaran. Seseorang yang memiliki motivasi belajar tinggi biasanya selalu merasa optimis dalam mengerjakan apa yang dikerjakan, sehingga mereka selalu merasa optimis untuk mencapai tujuan yang ingin dicapai (Djali, 2000).

Motivasi belajar timbul sebagai proses psikologis yang diakibatkan oleh faktor di dalam diri seseorang tersebut yang disebut faktor instrinsik. Faktor dari dalam diri tersebut antara lain kepribadian, sikap, pengalaman dll. Keadaan yang dialami oleh peserta didik dengan motivasi rendah adalah mereka cenderung membaca materi ala kadarnya tanpa adanya kemauan untuk mau memahami materi tersebut. Pada saat mengerjakan tugas, mereka yang memiliki motivasi rendah juga sering putus asa, acuh tak acuh, menyerah, dan mengandalkan teman ketika menemui hambatan dalam proses pembelajaran. Tidak adanya keinginan untuk bersaing dengan temannya juga memperlihatkan sikap yang pasif serta tidak adanya kemauan untuk menghasilkan kreatifitas.

Hasil hipotesis ketiga menyatakan adanya interaksi yang signifikan antara perbedaan paket pembelajaran dan perbedaan motivasi dalam mempengaruhi hasil belajar. Hasil penelitian didapatkan nilai $F_{\text {hitung }}$ sebesar 1,796 dengan Sig. 0,047. Karena nilai Sig. $<0,05$ maka $\mathrm{H}_{0}$ ditolak dan $\mathrm{H}_{1}$ diterima, maka disimpulkan ada interaksi signifikan antara hasil belajar antara yang menggunakan Paket Pembelajaran dan buku teks serta perbedaan motivasi dalam memberikan pengaruh terhadap hasil belajar Pengantar Pendidikan.Paket pembelajaran dan motivasi belajar memiliki interaksi yangsignifikan terhadap hasil belajar. Dengan paket pembelajaran dan motivasi belajar akan berpengaruh terhadap hasil belajar peserta didik. Hal ini dikarenakan motivasi belajar memicu rasa ingin berusaha peserta didik untuk mencapai tujuan pembelajaran, jika motivasi tinggi rasa berusaha juga tinggi tapi sebaliknya jika motivasi rendah rasa berusaha juga rendah. Sedangkan paket pembelajaran memungkinkan untuk mencapai tujuan pembelajaran lebih cepat. 


\section{SIMPULAN}

Simpulan yang didapat dalam penelitian ini adalah : 1) adanya perbedaan antara mahasiswa yang diajar menggunakan paket pembelajaran dan yang diajar menggunakan buku teks. Hasil belajar kelompok eksperimen memiliki nilai lebih tinggi dari pada kelompok kontrol. 2) adanya perbedaan hasil belajar pada mahasiswa dengan motivasi tinggi dan motivasi rendah. Hasil belajar mata kuliah pengantar pendidikan dengan motivasi tinggi lebih baik daripada motivasi rendah. 3) ada interaksi signifikan antara perbedaan penggunaan paket pembelajaran dan perbedaan motivasi belajar dalam memberikan pengaruh yang berbeda terhadap hasil belajar mata kuliah pengantar pendidikan.

\section{DAFTAR PUSTAKA}

Dick; \& Carey. (1996). The systematic design of instruction. New York: Harper Collins Publisher

Djali. (2000). Psikologi Pendidikan. Jakarta: PPs Universitas Negeri Jakarta

Gagne, R. (1975). Essentials Of Learning For Instruction. Hindale: The Dryen Press

Leatemia, M. (2008). Pengembangan Paket Pembelajaran Mata Kuliah Bahasa Inggris Teknik I Dengan Pendekatan 1 Konstektualisme Fungsional Materi Esp (English For Specific Purpose) Untuk Mahasiswa Teknik Mesin Pada Politeknik Negeri Ambon. Skripsi. UM. Malang

Notoatmojo, S. (2003). Pendidikan Dan Perilaku Kesehatan. Jakarta: PT Rineka Cipta

Romiszowski, A.J. (1986). Developing Auto-Instructional Materials. London: Routledge

Saadah, L. (2007). Implementasi Paket Pembelajaran Dengan Model Siklus Belajar 5e Dalam Upaya Meningkatkan Keterampilan Bertanya Guru Dan Hasil Belajar Siswa Smpn 4 Malang. Skripsi. UM. Malang

Sardiman, A.,M .(2011). Interaksi dn Motivasi Belajar Mengajar. Jakarta: PT Raja Grafindo Persada

Seniati, L., Yulianto, A,; \& Setiadi, B, N. (2005). Psikologi Eksperimen. Jakarta: Gramedia

Slavin, E.R. (2005).Cooperative Learning: Teori, Riset, Dan Praktik. Terjemahan oleh Narulta Yusron. Bandung: Nusa Medika

Sudjana, N. (2014). Penilaian Hasil Proses Belajar Mengajar. Bandung: PT Remaja Rosdakarya

Undang-undang Republik Indonesia Nomor 20 Tahun 2003 tentang Sistem Pendidikan Nasional 